\title{
Screen Printing the Glassware as Souvenir to Increase Selling Value and Income on Handicraft Group in Karangrejo, Jember, East Java
}

\author{
Author \\ Ilham Saifudin, Nurhalimah \\ Correspondence \\ Universitas Muhammadiyah Jember \\ ilham.saifudin@unmuhjember.ac.id,halimah@unmuhjember.ac.id
}

\begin{abstract}
Glasses / mugs and plates have a function as tableware, it also has a function as souvenirs that we can adjust to the desired character and look attractive, so that it has high value to sell. The method used to make souvenirs of glasses / mugs and plates is by means of a screen printing technique with digital printing. Screen printing techniques with digital printing on glasses / mugs and plates are done by a press machine, so that they can be decorated by using names, images according to the desired order. The development of souvenirs of glasses / mugs and plates in Jember is still rarely found. It can be proved, in each shop there are only a few which sell it, but are not produced by themselves. This has become an attractive and beneficial business opportunity for the economic development of the Handycraft Group and the Sekar Kartini Women's Cooperative members whose businesses have been declining recently. Thus, the specific target to be achieved is the establishment of a business unit for souvenirs of character glasses / mugs and plates by using appropriate technology, namely screen-printing presses and digital printing, and marketing management with the help of information technology (social media).
\end{abstract}

Keywords: press machine, glasses / mugs, plates, business unit, information technology

\section{Introduction}

Various household furniture is one of the most looked for products and demanded by the community as a tool for working on various household activities. The variety of activities is of various types, so it requires a lot of furniture. One example is most often used in daily needs, namely eating and drinking equipment, includes: glasses / mugs and plates. Various forms of it are made to fulfill people's needs.

On the other hand, it functions as tableware, also has a function as souvenirs that we can adjust to the desired character and look attractive, so that it has high value (Audrey, 2013). The method used to make souvenirs of glasses / mugs and plates is by means of a screen printing technique with digital printing. Screen printing technique with digital printing on glasses / mugs and plates is done by a press machine, so that it can be decorated by using names, images according to the desired order (Hartanto, 2015). A glass or mug can be in the form of ceramic / porcelain and glass. For example, in the event of weddings and graduations at the University level and the school level which are held increasingly prevalent (Keramik88.com, 2015). Apart from being a function as souvenirs,
Received: 07 Januari 2019. Accepted: 23 Januari 2019

we can use glasses or mugs to serve tea, coffee or other drinks. This is very interesting and proud while serving a cup of drink to guests who come to our homes. Because on the glasses or mugs are listed photos or characters decorated with our pictures/names.

The product development of souvenirs of glasses/ mugs and plates in Jember is still rarely found. It can be proven, that in each shop there are only a few which sell it, but are not produced it by themselves. The shapes and images printed on glasses or mugs are less varied, so souvenirs of it are still of little interest in Jember Regency. In terms of ordering and making, character glasses / mugs and plates with screen printing techniques take a long time, because there are no craftsmen who produce it. Producers of it are still dominated by craftsmen outside Jember. From the results of surveys in several shops in Jember, the prices of glasses / mugs with characters in some markets are between Rp. 25,000 to Rp. 35,000. The price depends on low or high material quality of mug. For the price of plain mugs or before printing by using digital printing ranges from Rp.10,000 to Rp.15,000. For the price of souvenirs character plates are not much different from souvenir glasses 
/ mugs. This has become an attractive and beneficial business opportunity for the economic development of the Handycraft Group and the Sekar Kartini Women's Cooperative members.

The Handycraft group, or the so-called handicraft group which is located in Karangrejo, Sumbersari, precisely to the east of the center of Jember, East Java. It focuses on making handicrafts (wedding gifts), bead bracelets, and woven mats. This group was established in 2015 and still continues to this day. The number of group members is 50 people. From the data obtained from the management of the Handycraft Group in a month can produce as many as $15-20$ handicraft products, the group has decreased if it is compared to the previous year which produced around 40-50. In addition, obtained from the site belonging to the Sumbersari published in 2016, the number of people who worked as craftsmen in the Karangrejo was still relatively small. The majority of the people in Karangrejo are mostly farmers. Where their work is not a job with a fixed salary, but they have an uncertain income. The community with a livelihood as farmers are 1,003 households, industry / handicrafts are 287 households, construction are 375 households, merchandising are in 978 households, and the rest (Transportation, Civil Servant or TNI / POLRI). It can be seen, that the industry / craft of households is still small in Karangerjo compared to other jobs. Based on data compiled from the Karangrejo office in 2016, on average, the majority of the Karangrejo people besides ASN generate a maximum income was Rp.1.100.000. The total income is still below minimum wage in Jember in 2017, which is Rp. 1.763.400 (Sumbersari, 2015). If it can be looked at the geographical location, the Handycraft Group works in the Karangrejo, where is near the economic center of Jember, which is close to the campus area. Among them: Jember University, State Polytechnic of Jember, IKIP PGRI Jember and Muhammadiyah Jember University. This makes Karangrejo as a strategic area in fulfilling the souvenir needs in promising Jember. In terms of product marketing, souvenir of character glasses / mugs and plates that have been made can work together with the closest cooperatives, one of them is Sekar Kartini Women's Cooperative. Sekar Kartini Women's Cooperative as the second partner is located on Sriwijaya VIII / 4 Karangrejo
Jember. The business sectors thatare run by Sekar Kartini Women's Cooperative are savings and loans, shops, carwash, rent cars, and driving courses. The task of Sekar Kartini Women's Cooperative manages the marketing management of making these souvenirs. Sekar Kartini Women's Cooperative has recently declined, the reasons are both in terms of savings and loans and stock items to be sold to consumers. With the cooperation between members of the Handycraft Group as producers and Sekar Kartinis Women's Cooperative as marketing, it will be beneficial for both parties.

\section{Implementation Method}

Based on the solutions and output targets proposed in the Community Partnership Program (PKM) activities, the stages in implementing the solutions described in the field of production activities are shown in Table 1, while financial and marketing management activities are shown in Table 1.

Table 1 Stages of Production Activities

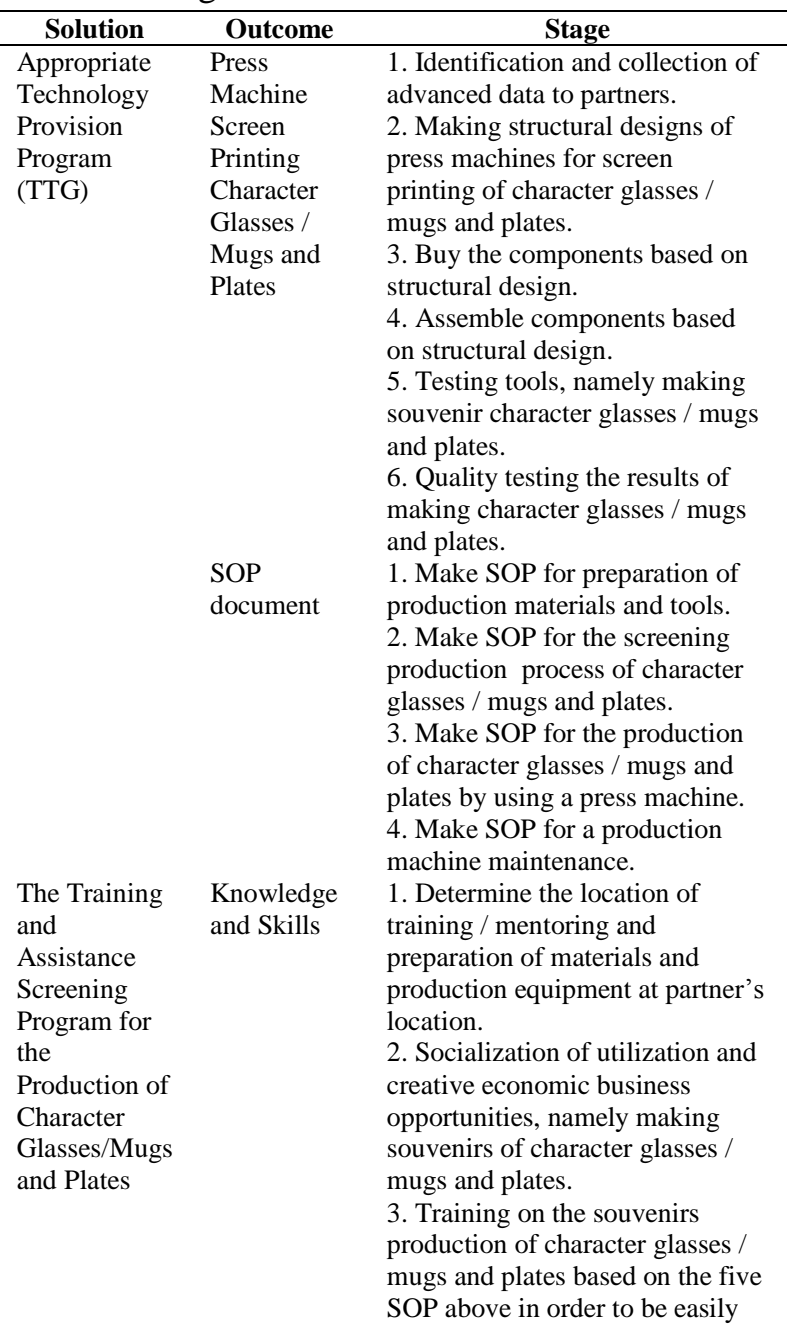




$\begin{array}{ll} & \begin{array}{l}\text { understood by both partners. } \\ \text { 4. Assistance to both partners so } \\ \text { that good cooperation and } \\ \text { communication are established. }\end{array} \\ \text { Independent } & \begin{array}{l}\text { 1. Continuous monitoring toward } \\ \text { participant skills and } \\ \text { Production } \\ \text { Capability }\end{array} \\ & \begin{array}{l}\text { implementation of production } \\ \text { activities in the form of regular } \\ \text { visits. }\end{array} \\ & \begin{array}{l}\text { 2. Evaluate the achievement level } \\ \text { of program targets and periodic } \\ \text { coaching for the emergence of } \\ \text { independent production. }\end{array} \\ \text { Collaboratio } & \begin{array}{l}\text { 1. Signing the cooperation } \\ \text { agreement between both partners } \\ \text { in the form of a legal agreement. }\end{array} \\ \text { Communica } & \text { 2. Product licensing to the } \\ \text { tion } & \text { Department of Industry. }\end{array}$

In the program for the provision of Appropriate Technology (TTG), the Proponent Team acts as (1) the provider and chooses the technology that will be used in making souvenirs based on the structural design that has been agreed by the partners, (2) testing the engine performance to be used in production activities (3) SOP documents makers make it based on designs that have been prepared previously. Both partners act as information providers regarding production capacity, production schedule, and feasibility of production results. The existence of solid cooperation and active participation in both partners will produce quality products and high selling value.

For training and mentoring programs for the manufacture of character glasses / mugs and plates by using a press machine, the proposing team acts as a trainer and companion to production activities, conducts evaluation monitoring and initiator of cooperation. While the two partners acted as trainees and mentors, owners and owners of entrepreneurial activities. Giving motivation in the form of exchanging opinions / discussion, question and answer, practice, continuous monitoring and evaluation is carried out in order to create independent creative efforts.

The following will explain the stages for financial management and marketing which can be seen in Table 2.

Table 2 Activity Stages in Financial Management and Marketing

\begin{tabular}{ccl}
\hline $\begin{array}{c}\text { Type of } \\
\text { Activity }\end{array}$ & \multicolumn{1}{c}{ Activity Steps } \\
\hline Finance & 1. & $\begin{array}{l}\text { Recording transaction evidence both expenses } \\
\text { and receipts. }\end{array}$ \\
& 2. & Making public journals. \\
& 3. & Posting to ledgers and trial balance. \\
& 4. & Making a completion journal. \\
& 5. & Making financial statements in the form of
\end{tabular}

balance sheets, profit and loss, changes in capital and cash flow.

Marketing 1. Making a product catalog that contains the kinds of products that are made and that will be ordered.

2. Creating social media accounts (facebook, twitter, and Instagram) containing various products that are made and will be ordered in order to find products easily and quickly.

3. Create an E-Commerce service account (tokopedia and bukalapak) containing the kinds of products that are made and will be ordered in order to find products easily and quickly.

4. Ensure the safety of goods ordered online by affixing the delivery receipt number. Whereas tokopedia and bukalapak have provided security features in shopping online inside.

5. Guarantee the products sold.

6. Filter satisfaction level of products that have been purchased by customers in the form of testimonials / questionnaires.

\section{Results and Outputs Reached}

In this Community Partnership Program (PKM) activities have been carried out which include preparation, testing of press and screen printing machines for mugs and plates as souvenirs, preparation of standard operating procedures, socialization to both partners, providing training and assistance in souvenir production practices, and marketing design using social media. The following are some of the activities that have been carried out in the Community Partnership Program.

\section{Preparation Activities}

The executive team carries out coordination activities on all parties involved. The parties involved included: chairman and executive member with the two target community partners (Handycraft and Sekar Kartini Women's Cooperative Jember Groups) represented by each chairperson on May 2018. This coordination activity was intended to develop a plan of service activities that would be done and distribution of tasks. Coordination of the Executive Team with the Chair of the Partner Group delivered in an agreement including: the implementation of the activities in the meeting room of the Sekar Kartini Jember Women's Cooperative, the members who will attend the event consisted of 30 members, and the implementation will be done in July 2018 by taking into account the days to be agreed further. No less important is the discussion about the design that will be delivered at the time of the activity in the form of training in making souvenirs by using screen printing press machines and how to sell them. The marketing socialization process 
will be carried out via the internet, including social media and e-commerce services.

\section{Preparation of Standard Operating Procedure (SOP) Activities}

The Standard Operating Procedure (SOP) of making souvenir character mugs and plates process by using a screen printing press consists of the preparation and manufacturing stages as follows:

\section{Preparation stage}

Be sure to assemble screen printing press machines mugs and plates are correct. The electricity needed when using a screen printing press has 1250 Watts. Prepare materials in the form of: plain mugs, plain plates, printers with sublime ink, 70 gram HVS paper Injet Paper, scissors, cutter, iron ruler, tissue, paper duct tape, and cleaning liquid.

\section{Making stage}

a. The following are the stages of making souvenir character mugs and plates by using a screen printing press machine. a. Design images which will be screened on mugs and plates using any application, for example photo paint, corel draw, etc. with a print design area of $20 \mathrm{~cm} \times 7.5 \mathrm{~cm}$ for mugs. While for plates $20 \mathrm{~cm} \times 20 \mathrm{~cm}$ according to the size of the plate area;

b. After printing, it is time to cut the paper according to the design print area by using a ruler and cutter;

c. Clean the glass surface before sticking the master image with tissue until it is completely clean;

d. Adhere master image on a glass using paper tape according to the desired area;

e. Turn on the screen printing press, then set the temperature to $380^{\circ} \mathrm{F}$ with duration up to 60 seconds according to the button printed on the machine to set it;

f. After step 7 is complete, it is time to put the glass / mug on the press machine and then the temperature will drop automatically;

g. While waiting, the temperature will automatically rise again until the predetermined temperature;

h. After reaching the maximum temperature, then press the "box" button and wait for the temperature to drop again until it reaches zero;

i. Press the "box" button again to turn off the engine alarm;

j. Finally take the glass that has been pressed with the screen printing press machine and clean it by using a cleaning liquid and dried using a tissue.

\section{Testing Activities of Screen Printing Press Machines}

The executive team has provided mugs and glasses screen printing press machines that are ready for performance testing to make character mug and plate souvenirs. Machine testing is carried out independently by the executive team and students involved in this activity. Machine testing activities carried out at Muhammadiyah Jember University.

Based on testing tools in producing mug and plate souvenirs are produced several working mechanisms (Hartanto, 2017), among others:

1. Be sure to assemble screen printing press machines mugs and plates are correct. The electricity needed when using a screen printing press has 1250 Watts;

2. Prepare materials in the form of: plain mugs, plain plates, printers with sublime ink, 70 gram HVS paper injet paper, scissors, cutter, iron ruler, tissue, paper duct tape, and cleaning liquid;

3. Design images to be screened on mugs and plates by using any application, for example photo paint, corel draw, etc. with a print design area of $20 \mathrm{~cm} \times 7.5 \mathrm{~cm}$ for mug. While for the plate $20 \mathrm{~cm} \times 20 \mathrm{~cm}$ according to the size of the plate area;

The following below is an example of a print setting for paper to be screened on a mug. Table 3 Print Paper Settings

\begin{tabular}{lll}
\hline Print Properties & HVS Paper 70 Gr & Inkjet Paper \\
\hline Quality Option & Best Photo & Best Photo \\
Paper Type & Epson Matte & Epson Matte \\
Paper Size & A4 & A4 \\
Mirror Options & Yes & Yes \\
\hline
\end{tabular}

4. After printing, it is time to cut the paper according to the design print area by using a ruler and cutter; 
5. Clean the glass surface before sticking the master image with the tissue until it is completely clean;

6. Adhere master image on a glass by using paper tape according to the desired area;

7. Turn on the screen printing press machine, then set the temperature to $380^{\circ} \mathrm{F}$ with the duration up to 60 seconds according to the button printed on the machine to set it;

8. After step 7 is complete, it is time to put the glass / mug on the press machine and then the temperature will drop automatically;

9. While waiting, the temperature will automatically rise again until the predetermined temperature;

10.After reaching the maximum temperature, then press the "box" button and wait for the temperature to drop again until it reaches zero;

11.Press the "box" button again to turn off the engine alarm;

12.Finally take the glass that has been pressed with the screen printing press machine and clean it by using a cleaning liquid and dried it by using a tissue. The following is the setting of mug press machine that can be seen in Table 4 .

Table 4: Mug Press Machine Settings

\begin{tabular}{ccccc}
\hline Machine & \multicolumn{2}{c}{ HVS Paper 70 Gr } & \multicolumn{2}{c}{ Inkjet Paper } \\
\cline { 2 - 5 } Settings & \multicolumn{2}{c}{${ }^{\circ} \mathrm{F}$} & ${ }^{\circ} \mathrm{C}$ & \multicolumn{2}{c}{${ }^{\circ} \mathrm{F}$} & ${ }^{\circ} \mathrm{C}$ \\
\hline Temperature & 380 & 190 & 380 & 190 \\
Time & 60 & 60 & 60 & 60 \\
\hline
\end{tabular}

Below is a picture of the trial implementation activities carried out by the executive team and assisted by Informatics Engineering students at the University of Muhammadiyah Jember.

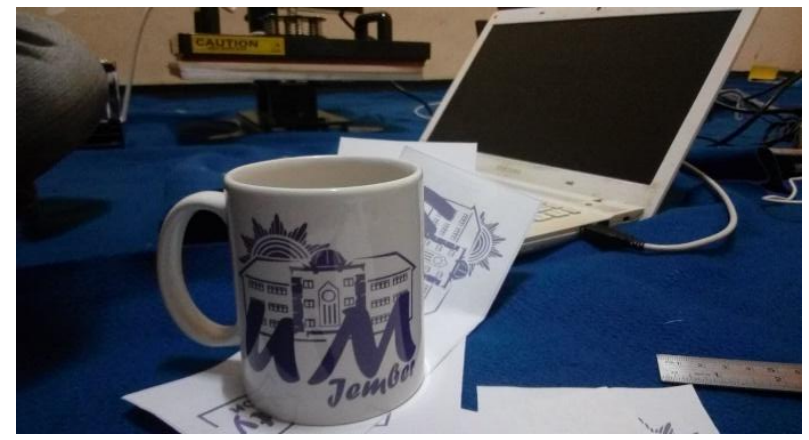

Figure 1 Results of the Press Machine Testing Process

\section{The Socialization Activity for Both Partners}

In this activity the executive team did a socialization program about the making of souvenirs character mugs and glasses using screen printing press machines for PKM Partners, such as the handycraft group and the Women's Cooperative of Sekar Kartini Jember. This activity is intended for representatives present at the socialization can tell to other members, that there will be held a training and mentoring about souvenirs charactermugs and glasses using a screen printing press machine. This activity was held in July 2018 at the Sekar Kartini Women's Cooperative in Karangrejo Jember and it was attended by several members of the Handycraft Group and the Sekar Kartini Jember Women's Cooperative. The following picture below is socialization activities of the PKM implementation at the Sekar Kartini Jember Women's Cooperative.

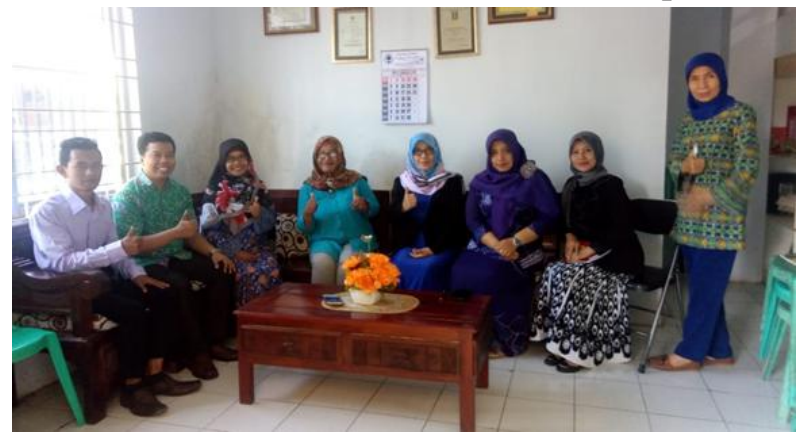

Figure 2 The Socialization Activities for PKM Implementation at Women's Cooperative of Sekar Kartini Jember

\section{Training and Mentoring Activities}

This training and mentoring activity was held on Monday 30 July 2018 at 10.00 until finish at the meeting room of the Sekar Kartini Jember Women's Cooperative. Participants who attended were 15 Members of the Handicraft Group in Karangrejo Jember. The activity run well like the previous plan. Starting in materials preparation and making screen printing press machines, the members were very enthusiastic. The following below is a training and mentoring activity in making souvenirs character mug using a screen printing press machine. 


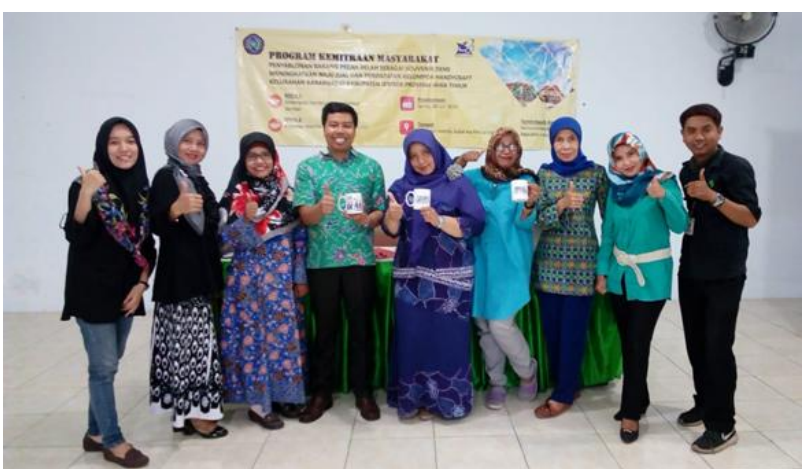

Figure 3 PKM Training and Mentoring Activities2018

\section{Marketing Design Activities}

Marketing design activities held on August, exactly on SaturdayAugust 04, 2018. The training place for marketing design in the meeting room of the Sekar Kartini Jember Women's Cooperative. The participants who attended the event were 21 members consisting Handycraft Group in Karangrejo Jember and the members of Sekar Kartini Jember Women's Cooperative. In this activity, an effective marketing strategy training was provided by using e-commerce and social media services. In addition, some knowledge is also provided on how to manage finances properly and correctly. Both by using simple bookkeeping and available applications in computer devices. For example, using an application like Microsoft Excel. This activity is so important to be carried out for the businesssustainability of souvenir character mugs and plates. Because basically, the business will run well if marketing and financial management are good too. The implementation of that activities run well like the previously planning. Similarly, when it was seen from the picture below, the participants were enthusiastic in listening the material that is given.

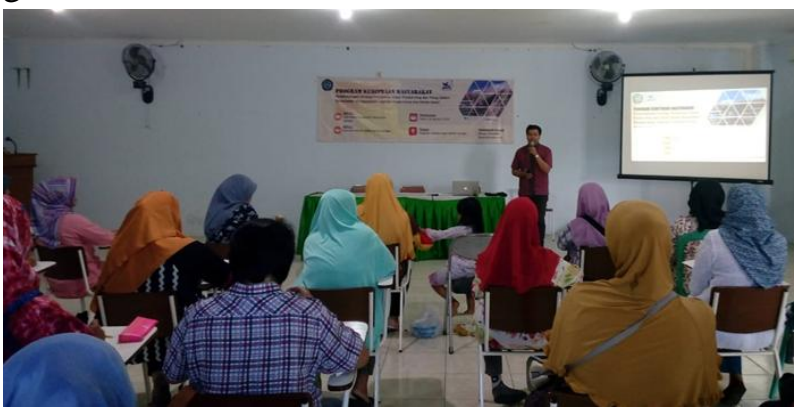

Figure 4 Marketing Planning and Financial Management Training Activities

\section{Conclusion}

The conclusion of the Community Partnership Program (PKM) activity was Screen Printing the Glassware as Souvenirs for Increasing Selling Value and income on Handicraft Group Karangrejo, Jember, East Java as follows:

1. The executive team has carried out the design activities in the form of well preparation with the aim to arrange plan of service activities to be carried out and tasks division;

2. The executive team has conducted testing on the tools, namely in the form of screen printing press machines, mugs and plates by using materials that have been provided previously. This activity was intended to produce Standard Operating Procedure (SOP) on the manufacture of character mugs and plates. Thus optimal production results are obtained and have high selling value;

3. The executive team has done socialization to PKM Partners regarding the activities that will be held in the form of training and mentoring in making character mugs and plates souvenir by using a screen printing press machine;

4. The executive team has conducted training and mentoring in the manufacture of character mugs and plates souvenir by using a screen printing press machine in good condition and smooth in accordance with the plans that have been prepared previously;

5. The executive team has conducted marketing planning training on character mugs and plates souvenir products by using E-commerce services and social media. In addition, given well training in financial management for the business sustainability of character mugs and plates.

\section{References}

Audrey, C. (2013). Panduan Membuat dan Menghias Antaran Maha dan Souvenir Pernikahan. Yogyakarta: Kawan Pustaka.

Hartanto, F. (2015). Membuat Dekorasi Gelas Souvenir dengan Kertas Decal dan Tinta SUblime. Surabaya.

Hartanto, F. (2017). Magic Trans Paper Solusi Transfer Gambar ke Mug Keramik tanpa Coating. Surabaya.

Keramik88.com. (2015, Januari Kamis). Mug Pernikahan Unik-Murah dan Berkualitas. Retrieved from Keramik88.com: 
http://keramik88.com/uncategorized/membua t-dekorasi-gelas-souvenir-dengan-kertasdecal-dan-tinta-sublime.html

Sumbersari, K. (2015, April Jumat). Mata Pencaharian Penduduk. Retrieved from Kecamatan Sumbersari: http://www.kecsumbersarijember.com/index. php/program-kegiatan/program-kegiatankecamatan-dalam-upaya-meningkatkankesejahteraan-masyarakat-tahun-2014/12mata-pencaharianpenduduk\%20(Diakses\%2008\%20Mei\%2020 17)

\section{Acknowledgement}

Thanks to the parties who have supported the implem 'entation of the Community Partnership Program (PKM) with the title "Screen Printing The Glassware as Souvenir to Increase Selling Value and Income on "Handycraft" Group in Karangrejo, Jember, East Java". These are some parties who have supported the event:

1. The ministry of higher education research and technology Republic Indonesia which has supported both funding and mentoring, so that this activity run well as the expectations;

2. LPPM (Institute for Research and Community Service) of Muhammadiyah Jember University which has provided some information and guidance so that this activity run well;

3. Muhammadiyah Jember University and all parties who involved in this PKM Activity. 